\section{The Impact of Eight Hybrid Tomato Rootstocks on 'BHN 589' Scion Yield, Fruit Quality, and Plant Growth Traits in a Midwest High Tunnel Production System}

Kristine M. Lang

Department of Horticulture, Iowa State University, 260 Horticulture Hall, Ames, IA 50011

\author{
Ajay Nair \\ Department of Horticulture, Iowa State University, 145 Horticulture Hall, \\ Ames, IA 50011
}

Kenneth J. Moore

Department of Agronomy, Iowa State University, 1571 Agronomy Hall, Ames, IA 50011

Additional index words. Solanum lycopersicum, soluble solids content, total titratable acids

\begin{abstract}
Prior work in a Midwestern United States high tunnel indicated that hybrid and heirloom tomato scions grafted to hybrid rootstock 'RST-04-106-T' had a minimal yield increase in the absence of soilborne disease pressure, which underscored the need for continued regional trials of alternative, commercially available tomato rootstocks. Objectives of the present study were to assess yield, fruit quality [pH, soluble solids content (SSC), total titratable acids (TTA), and firmness], and plant growth traits (plant height, stem diameter, and biomass) of grafted tomato with eight different hybrid rootstocks. 'BHN 589', a determinate hybrid tomato, was grafted to 'Arnold', 'Beaufort', 'DRO141TX', 'Estamino', 'Maxifort', 'RST-04-106-T', and two trial rootstocks, '946 TRS' and '980 TRS'. Research was conducted April to September in 2017 and 2018 in a 9.1-m wide $\times 29.2-\mathrm{m}$ long $\times 3.7-\mathrm{m}$ tall single-poly high tunnel located at the Iowa State University Horticulture Research Station, Ames, IA. There were five plants per treatment in a randomized complete block design with five replications. Weekly harvests took place 13 times each season. 'BHN 589' grafted to 'Arnold', 'Beaufort', 'DRO141TX', 'Estamino', or 'Maxifort' had $30 \%$ to $119 \%$ more marketable fruit and had a higher marketable fruit weight by 1.3 to $4.1 \mathrm{~kg}$ per plant compared with nongrafted plants. Fruit quality differences were minimal in 2017 and null in 2018, as indicated by fruit pH, SSC, TTA, and the SSC:TTA ratio. The same five high-yielding rootstock treatments were the tallest, ranging from 184 to $214 \mathrm{~cm}$ in height. In 2017, shoot biomass of 'BHN 589' grafted to 'Arnold', 'Beaufort', 'DRO141TX', 'Estamino', and 'Maxifort' was 59 to $100 \mathrm{~g}$ more than that of nongrafted plants; in 2018, 'BHN 589' grafted to 'Maxifort' and 'DRO141TX' had the largest shoot biomass at 386 and $315 \mathrm{~g}$, respectively. Overall, the results of this study indicate that 'Arnold', 'DRO141TX', and 'Estamino' may be comparable in performance to the widely used rootstocks 'Beaufort' and 'Maxifort' when grown under conditions lacking biotic or abiotic stress. Our results provide promising new options for Midwestern U.S. growers of high tunnel tomato who are seeking high-performing rootstocks.
\end{abstract}

The number of farms growing tomato under protection in Iowa increased by $32 \%$ between 2012 and 2017 (USDA, 2019a), while open-field production of tomato has decreased (USDA, 2019b). The shift away from openfield production of tomato can be attributed, in part, to the increased popularity of high tunnel production systems driven by the implementation of the seasonal High Tunnel Initiative in 2009 through the Natural Resources Conservation Service's Environmental Quality Incentives Program (Bruce et al., 2017; Carey et al., 2009; Enderton et al., 2017).

High tunnels are an important tool to extend the growing season (Lamont, 2009;
2019), crops within high tunnels are afflicted by increased soil salinity (Knewtson et al., 2010), changes in fertility management (Reeve and Drost, 2012), and increased soilborne disease pressure (Kubota et al., 2008) compared with field production. Although crop rotation could aid in mitigating some of these issues, continuous cropping of tomato in high tunnels remains common practice as growers seek to maximize their return on investment (Bruce et al., 2019). Due to concerns about increased risks associated with continuous tomato cropping, vegetative grafting of tomato has become an important tool for high tunnel production (Albacete et al., 2015; Kubota et al., 2008; Lee et al., 2010; Loewen, 2018; Louws et al., 2010; Meyer, 2016).

In multiple studies of high tunnel tomato production systems, grafting increased yield (Loewen, 2018; Meyer, 2016) and improved resistance to several soilborne diseases including root-knot nematode (Barrett et al., 2012b), verticillium wilt (Buller et al., 2013; Liu et al., 2009), Fusarium crown and root rot (Vitale et al., 2014), and bacterial wilt (McAvoy et al., 2012). In multiple field settings, grafting reduced the response to abiotic stresses including organic pollutants (Schwarz et al., 2010), suboptimal temperatures (Ntatsi et al., 2014; Schwarz et al., 2010; Suchoff et al., 2018a), drought conditions (Bhatt et al., 2015; Nilsen et al., 2014; Schwarz et al., 2010), and improved water use efficiency (Suchoff et al., 2018b). Grafting has also improved the nutrient use of scions (Djidonou et al., 2013, 2015; Leonardi and Giuffrida, 2006; Schwarz et al., 2013), and aided plants in overcoming salinity stress (Di Gioia et al., 2013; Martinez-Rodriguez et al., 2008).

Even with all the demonstrated benefits of grafting there is still a lack of consistency in the response of scion $\times$ rootstock combinations across various locations. A recent metaanalysis by Grieneisen et al. (2018) found that grafting increased marketable yield in only $35 \%$ of the studies they reviewed. Kubota et al. (2008) first emphasized the importance of localized rootstock trials to assess the feasibility of vegetable grafting, and the importance of conducting local trials was affirmed recently (Albacete et al., 2015; Grieneisen et al., 2018).

In Iowa, the rootstock 'RST-04-106-T' grafted to both a hybrid and heirloom tomato grown under high tunnel conditions provided only marginal yield increases, reduced fruit quality, and had similar shoot biomass when compared with a nongrafted control (Lang and Nair, 2019). Although results from the initial grafting study demonstrated that 'RST-04-106-T' may not be the best rootstock for tomato grafting if there is not soilborne pathogen pressure (Lang and Nair, 2019), there was great interest from growers to identify alternative rootstocks for Midwest production. The objective of our study was to review the performance of 1) proven, 2) less studied, and 3 ) new hybrid tomato rootstocks in a high tunnel system with no history of 
soilborne disease pressure. We expected to see differences in yield, fruit quality, and plant growth traits among the rootstocks as compared with nongrafted and self-grafted controls. Our goal was to form a recommendation of top-performing rootstocks for use in Midwest high tunnel production systems.

\section{Materials and Methods}

Scion and rootstock selection. 'BHN 589', a hybrid, determinate tomato was selected as the scion for this research, as it is commonly used by growers within Iowa and has also been used previously in other central U.S. trials (Loewen, 2018; Louws et al., 2010; Masterson et al., 2016; Meyer, 2016). Nongrafted and self-grafted 'BHN 589' were compared with 'BHN 589' grafted onto eight different rootstocks (Table 1). 'RST-04-106T' (Lang and Nair, 2019) was included in this study along with two trial rootstocks provided by Sieger's Seed Co. (Holland, MI) (Table 1). An additional five commercially available rootstocks were used in this study. Two well-studied rootstocks that have proven valuable in a variety of field conditions were 'Beaufort' (Buller et al., 2013; Djidonou et al., 2013, 2015, 2016; Leonardi and Giuffrida, 2006; Nicoletto et al., 2013; Suchoff et al., 2018b; Turhan et al., 2011) and 'Maxifort' (Kunwar et al., 2015; Loewen, 2018; Louws et al., 2010; Masterson et al., 2016; Meyer, 2016; Rivard and Louws, 2008; Rivard et al., 2010a, 2010b; Schwarz et al., 2013). Two rootstocks that have not been extensively studied were included in the trial: 'Arnold' (Di Gioia et al., 2013; Meyer, 2016; Turhan et al., 2011) and 'Estamino' (Miles et al., 2015). Finally, the rootstock 'DRO141TX' was included as it is being promoted within the industry as a replacement for 'Maxifort', but the authors could not find any existing, independent research to support these claims.

Site description. Research was conducted during Summer 2017 and 2018 at the Iowa State University Horticulture Research Station in Ames, IA, in a 9.1-m wide $\times 3.7-\mathrm{m}$ tall $\times 29.3-\mathrm{m}$ long ClearSpan high tunnel (FarmTek, Dyersville, IA) covered with single-layer 6-mil polyethylene film

Received for publication 21 Nov. 2019. Accepted for publication $10 \mathrm{Apr} .2020$.

Published online 15 May 2020.

We thank North Central Sustainable Agriculture Research and Education Professional Development Grant (ENC17-161) for supporting this research and extension project. We express immense gratitude to all undergraduate research assistants who provided support with field management, data collection, and sample analysis during this project. K.M.L. is a PhD Candidate.

A.N. is an Assistant Professor.

K.J.M. is a Distinguished Professor.

A.N. is the corresponding author. E-mail: nairajay@ iastate.edu.

This is an open access article distributed under the $\mathrm{CC}$ BY-NC-ND license (https://creativecommons.org/ licenses/by-nc-nd/4.0/).

Table 1. Seed developer and seeding dates for 'BHN 589' hybrid tomato scion and eight tomato rootstocks grown in the Iowa State University Department of Horticulture, Ames, IA, greenhouse in 2017 and 2018.

\begin{tabular}{|c|c|c|c|}
\hline \multirow[b]{2}{*}{ Cultivar } & \multirow[b]{2}{*}{ Developer } & \multicolumn{2}{|c|}{ Seeding date } \\
\hline & & 2017 & 2018 \\
\hline BHN 589 & $\begin{array}{c}\text { Scion } \\
\text { BHNSeed, Immokalee, FL } \\
\text { Rootstocks }\end{array}$ & 14 Mar. & 26 Feb. \\
\hline 946 TRS & Sieger's Seed Co., Holland, MI & 17 Mar. & 1 Mar. \\
\hline 980 TRS & Sieger's Seed Co., Holland, MI & 17 Mar. & 1 Mar. \\
\hline Arnold & Syngenta, Basel, Switzerland & 19 Mar. & 4 Mar. \\
\hline Beaufort & De Ruiter, St. Louis, MO & 18 Mar. & 2 Mar. \\
\hline DRO141TX & De Ruiter, St. Louis, MO & 18 Mar. & 2 Mar. \\
\hline Estamino & Enza Zaden, Salinas, CA & 17 Mar. & 1 Mar. \\
\hline Maxifort & De Ruiter, St. Louis, MO & 16 Mar. & 28 Feb. \\
\hline RST-04-106-T & DP Seeds, Yuma, AZ & 17 Mar. & 1 Mar. \\
\hline
\end{tabular}

(TuffliteIV Clear; Berry Global Inc., Evansville, IN). The high tunnel was equipped with motorized roll-up sides set to open when the temperature at $1 \mathrm{~m}$ above the soil was $\geq 23.8{ }^{\circ} \mathrm{C}$ according to a sensor attached to a thermostat control panel (PosiClasp Roll-Lock VCU1; Advancing Alternatives, Lancaster, PA).

From 12 Sept. to 11 Nov. 2016 the high tunnel was used to grow pak choi (Brassica rapa subsp. Chinensis), cauliflower (Brassica oleracea), and lettuce (Lactuca sativa). The soil within the high tunnel was a Clarion loam. Soil samples taken at time of planting in both 2017 and 2018 indicated $4.5 \%$ organic matter, cation exchange capacity of $22.0 \mathrm{meq} / 100 \mathrm{~g}$, and $\mathrm{pH}$ of 7.5 ; and $3.7 \%$ organic matter, cation exchange capacity of $24.8 \mathrm{meq} / 100 \mathrm{~g}$ and $\mathrm{pH}$ of 7.4 in respective seasons. Irrigation water was sourced from a pond located at the research station.

To monitor ambient air temperature, data loggers (Hobo Pendant Temperature/Light data loggers UA-002-8; Onset Computer Corporation, Bourne, MA) were placed inside of the high tunnel $30 \mathrm{~cm}$ above the soil line and programmed to collect data every $1 \mathrm{~h}$ during each growing season. Data were collected during the entire growing season in 2017, but collection ceased on 9 Sept. 2018 because of a sensor malfunction.

Transplant production. All transplants were grown in the Iowa State University Department of Horticulture greenhouse maintained at 20 to $22{ }^{\circ} \mathrm{C}$ from 0600 to $2200 \mathrm{HR}$ and 17 to $19{ }^{\circ} \mathrm{C}$ from 2200 to 0600 HR. Supplemental irradiance was provided during 0600 to $2200 \mathrm{HR}$ with $1000 \mathrm{~W}$, highpressure sodium bulb (AgroMax, Summerdale, AL).

In 2017 , a preliminary germination trial of the scion and all rootstocks indicated differences in germination time, and seeding dates were adjusted to obtain uniform seedlings at the time of grafting (Table 1). Seeds were sown in 288-cell propagation trays, and plugs were transplanted on 26 Mar. 2017 and 8 Mar. 2018 to 72-cell trays (scion) and 606-cell packs (rootstocks). All trays and cell packs were filled with a soilless potting mix (Metro Mix 360; Sun Gro Horticulture, Agawam, MA).

On 5 Apr. 2017 and 20 Mar. 2018, seedlings were grafted using the splice grafting method (Lee et al., 2010) and the same grafting and healing methods detailed in Lang and Nair (2019) were used for the present study. One week after grafting, plants were removed from the healing chamber and acclimated to ambient greenhouse conditions. The nongrafted treatment remained in ambient greenhouse conditions throughout the growing period. Plants were watered as needed and fertilized with $\mathrm{N}$ at $150 \mathrm{mg} \cdot \mathrm{L}^{-1}(15-5-15$ Peters Excel Multi-Purpose and Cal-Mag; Everris International, Geldermalsen, The Netherlands), four times in 2017 [8, 24, 29, and $31 \mathrm{~d}$ after seeding (DAS) $]$ and seven times in $2018(4,5,9,24,26,35$, and 43 DAS).

Field design and management. Before planting each season, $145.7 \mathrm{~kg} \cdot \mathrm{ha}^{-1} \mathrm{~N}$ (Sustane All Natural Granulated Slow Release Nitrogen Fertilizer 4-6-4, Inc., Cannon Falls, $\mathrm{MN})$ was incorporated into the soil in the high tunnel with rotary tillage. In 2017, black plastic mulch, $0.9 \mathrm{~m}$ wide (Pliant Corporation, Schaumburg, IL), was installed before planting. The entire high tunnel was mulched to a depth of $15 \mathrm{~cm}$ with dried switchgrass (Panicum virgatum); in 2017, the mulch was between the plastic rows and in 2018, the mulch covered the entire soil surface up to the tomato stems.

Tomatoes were transplanted into the high tunnel on 21 Apr. 2017 and 20 Apr. 2018. The experimental design was a randomized complete block with five replications (rows) running the length of the high tunnel, oriented east to west, with $1.4 \mathrm{~m}$ between rows. The 10 treatments in each row included nongrafted and self-grafted 'BHN 589' and 'BHN 589' grafted to each of the eight rootstocks. Each treatment plot contained five plants spaced $0.46 \mathrm{~m}$ apart within rows.

All tomatoes were grown with a stake and weave support system using wooden and metal stakes and tomato twine (Professional Grade Tomato Twine; Berry Hill Irrigation, Inc., Buffalo Junction, VA). Plants were pruned with leaf axil shoots removed from the base of the plant up to the first fruit cluster.

Drip tape (Aqua-Traxx; Toro, Bloomington, $\mathrm{MN}$ ) with $20.3 \mathrm{~cm}$ emitter spacing and $1.39 \mathrm{~L} \cdot \mathrm{min}^{-1}$ was used in both seasons to apply irrigation up to $2.54 \mathrm{~cm} \cdot \mathrm{week}^{-1}$ depending on crop stage. During the season, fertilizer was applied through the drip tape with an injector (D14MZ2; Dosatron 
International, Clearwater, FL) at rate of 250 to $300 \mathrm{mg} \cdot \mathrm{L}^{-1} \mathrm{~N}$ (Nature's Source Professional Plant Food 10-4-3; Ball DPF, LLC, Sherman, TX). Applications occurred at 21, 46, 48, 60, 61, 70, 90, 101, and $103 \mathrm{~d}$ after transplanting (DAT) in 2017 and 94, 99, 118, and 123 DAT in 2018.

A 50\% shadecloth (Nolt's Midwest Produce Supplies, Charles City, IA) was placed over the top of the high tunnel to reduce irradiance and to moderate temperature from 14 June to 23 Aug. 2017 and 19 June to 16 Aug. 2018. In 2018, a malfunction of the automated roll-up sides (ventilation system) led to temperatures within the high tunnel that exceeded $40{ }^{\circ} \mathrm{C}$ for $9 \mathrm{~h}$ on both 4 May and 5 May before the problem was resolved. Due to the damage from excessive temperatures, $35 \%$ of plants were lost in a random pattern across the high tunnel. On 7 May, all dead plants were replaced with new transplants, and management of the crop resumed as scheduled with some noticeable delays in plant growth. Crops were scouted weekly for signs of insect pests and disease symptoms. Except for heat damage in 2018, no biotic or abiotic stress symptoms were noted in either season. Major insect pests were corn earworm (Helicoverpa zea) and tobacco hornworm (Manduca sexta), which were controlled by spraying Bacillus thuringiensis subspecies kurstaki, strain ABTS-351 (DiPel PRO DF; Valent U.S.A. Corp., Walnut Creek, CA), applied once in 2017 and four times in 2018 at a rate of 1.1 $\mathrm{kg} \cdot \mathrm{ha}^{-1}$ a.i.

Harvest. Harvest occurred weekly from 5 July to 26 Sept. 2017 and 3 July to 25 Sept. 2018 for a total of 13 harvests each season. Tomato fruit were harvested at the breaker stage and were graded according to U.S. Department of Agriculture (USDA) standards [Grade 1: diameter $>5.9 \mathrm{~cm}$; Grade 2: $6.4 \mathrm{~cm}<$ diameter $<5.9 \mathrm{~cm}$, and Grade 3: $5.7 \mathrm{~cm}<$ diameter $<6.4 \mathrm{~cm}$ (U.S. Department of Agriculture, 1991a, §51.1859)]. To determine size, tomatoes were gently dumped onto a sorting table where fruit of smaller sizes dropped through holes that corresponded to each USDA grade. Nonmarketable fruit were smaller than $5.7 \mathrm{~cm}$ diameter and/or damaged by blossom end rot, catfacing, yellow shoulder, insects, or other surface defects. Fruit count and weight were recorded for all categories for each harvest.

Fruit quality. To assess firmness, SSC, $\mathrm{pH}$, and TTA, Grade 1 marketable fruit were selected from each plot by tagging fruit at breaker stage (U.S. Department of Agriculture, 1991b, §51.1860)] at 118 and 109 DAT in 2017 and 2018, respectively, and harvesting $7 \mathrm{~d}$ later (Taber et al., 2008). One day after harvest, all fruit were processed in a laboratory with average temperature of $21{ }^{\circ} \mathrm{C}$. One whole fruit from each sample was selected for analysis of SSC $(n=50)$. A penetrometer (Model 30B; Ballauf Devices, Derwood, MD) was used on marketable fruit to measure firmness. Four measurements were taken equatorially, $90^{\circ}$ apart on each uncut fruit.
After firmness was collected, each fruit was blended in a food processor (Model \#FP1700B; Black+Decker, Beachwood, $\mathrm{OH})$ for $1 \mathrm{~min}$, strained through six layers of cheesecloth into a clean weight boat, and 1 $\mathrm{mL}$ of the extract was transferred to a digital refractometer (Pocket Pal-1 refractometer; Atago, Tokyo, Japan). Three 1-mL subsamples from each fruit were analyzed and the refractometer was cleaned and calibrated between each treatment using deionized water.

The same fruit extract which was prepared for SSC analysis was also used to analyze TTA in each respective year. In 2017, after SSC analysis, samples were stored in $30-\mathrm{mL}$ bottles and stored frozen at $-20{ }^{\circ} \mathrm{C}$ until time of TTA analysis, and in $2018 \mathrm{SSC}, \mathrm{pH}$, and TTA analysis all occurred on the same day. Initial $\mathrm{pH}$ was recorded, and TTA, as percent citric acid milliequivalents, was determined by potentiometric titration of $5 \mathrm{~mL}$ of tomato extract in $45 \mathrm{~mL}$ of deionized water to an endpoint of $\mathrm{pH}=8.1$ with sodium hydroxide using an automatic titrator (HI 84532 Minititrator; Hanna Instruments Inc., Woonsocket, RI)

Plant growth. The experiment was ended on 26 Sept. 2017 and 26 Sept. 2018 on which date all end-of-season plant growth traits were collected. Stem diameter and plant height were measured on the three plants in middle of each plot $(n=150)$. Plant height was measured from the soil line to the growing point of each plant. Stem diameter was measured using digital calipers (Westward model \#2YNC6; Grainger Inc., Burr Ridge, IL) $1 \mathrm{~cm}$ above the graft union for all grafted treatments and $2 \mathrm{~cm}$ above the soil line for nongrafted controls.

The same three plants in each plot were collected to determine biomass by gathering all shoot tissue and digging a $45-\mathrm{cm}$ diameter $x$ $45-\mathrm{cm}$ deep hole to collect a uniform root sample. Shoot and root tissue were separated at the grafted union for grafted plants and $1 \mathrm{~cm}$ above the soil for nongrafted controls. All material was collected in brown paper lawn bags, transported to the Iowa State University Agronomy Research Farm, Ames, IA, and dried at $67^{\circ} \mathrm{C}$ in forced-air drying rooms for $5 \mathrm{~d}$. Once all moisture was removed, dried tissue was weighed using a 4000-g scale (Scout Pro SPE4001; Ohaus Corporation, Parsippany, NJ).

Data analysis. Data from the 2017 and 2018 experiments were analyzed separately because of the large number of treatment $x$ year interactions. Analysis of variance was conducted using the GLIMMIX procedure in SAS (version 9.4; SAS Institute, Cary, NC). Within each season, all response variables were analyzed with rootstock as a fixed term tested against the random term of block and the block by rootstock interaction (residual). Analysis of conditional residuals for each response variable indicated no deviation from homogeneity or normality assumptions; therefore, data transformation was not needed. To account for field variability while avoiding type II errors, all treatment means were separated using the unrestricted least significant difference procedure $(\alpha=$ $0.05)$.

\section{Results}

Overall, the air temperatures were warmer within the high tunnel in 2018 as compared with the 2017 growing season, with maximum temperatures spiking more frequently in the 2018 season (Fig. 1). Below-average temperatures at time of planting in 2018 are evident in Fig. 1.

\section{Number of marketable and nonmarketable fruit per plant}

Within each year, the total number of marketable fruit per plant was greatest when 'BHN 589' was grafted to 'Arnold', 'Beaufort', 'DR0141TX', 'Estamino', or 'Maxifort' compared with nongrafted 'BHN 589' (Table 2). The increase in total marketable fruit per plant for these 'BHN 589' grafted to these five rootstocks ranged from $30 \%$ ('Beaufort') to 47\% ('DRO141TX') in 2017 and $86 \%$ ('Estamino') to $119 \%$ ('DRO141TX') in 2018 (Table 2).

When divided into Grades 1, 2, and 3, the number of marketable fruit per plant varied by rootstock within each grade. Grade 1 number of marketable fruit per plant followed the same pattern as total marketable fruit yield (Table 2). Grade 2 number of marketable fruit per plant was greatest on 'Maxifort' in 2017 and 'Beaufort' and 'DRO141TX' in 2018 (Table 2). Grade 3 number of marketable fruit per plant increased only in 2017 from 'Arnold' and 'DRO141TX' (Table 2).

The total number of nonmarketable fruit per plant was highest from 'Arnold', 'DRO141TX', and 'Maxifort' in 2017 and from 'Arnold', 'Beaufort', 'Estamino', and 'Maxifort' in 2018 (Table 2). The incidence of blossom end rot (BER) was lower on fruit from 'Estamino' and 'Maxifort' rootstocks compared with nongrafted plants, but this pattern was observed only in 2017 (Table 2). Fruit from 'BHN 589' grafted to 'RST-04106-T' had a higher incidence of BER in 2017 when compared with all other treatments. Catfacing was not reduced by the grafted treatments in either year; conversely, in 2018, fruit from 'Beaufort' and 'Maxifort' had an increased incidence of catfacing (Table 2).

\section{Weight of marketable and nonmarketable fruit per plant}

The total weight of marketable fruit per plant was higher on 'BHN 589' grafted to 'Arnold', 'Beaufort', 'DRO141TX', 'Estamino', and 'Maxifort' as compared with the nongrafted control in both years, but only in 2017 for 'BHN 589' grafted to '980 TRS' (Table 3). The increase in total weight of fruit per plant for the high-yielding rootstock treatments over the nongrafted control ranged from $1.3 \mathrm{~kg}$ ('980 TRS') to $3.4 \mathrm{~kg}$ ('Estamino') in 2017 and $3.4 \mathrm{~kg}$ ('Estamino') to $4.1 \mathrm{~kg}$ ('DRO141TX') in 2018 (Table 3).

The weight of Grade 1 marketable fruit reflected the same pattern as observed for the 

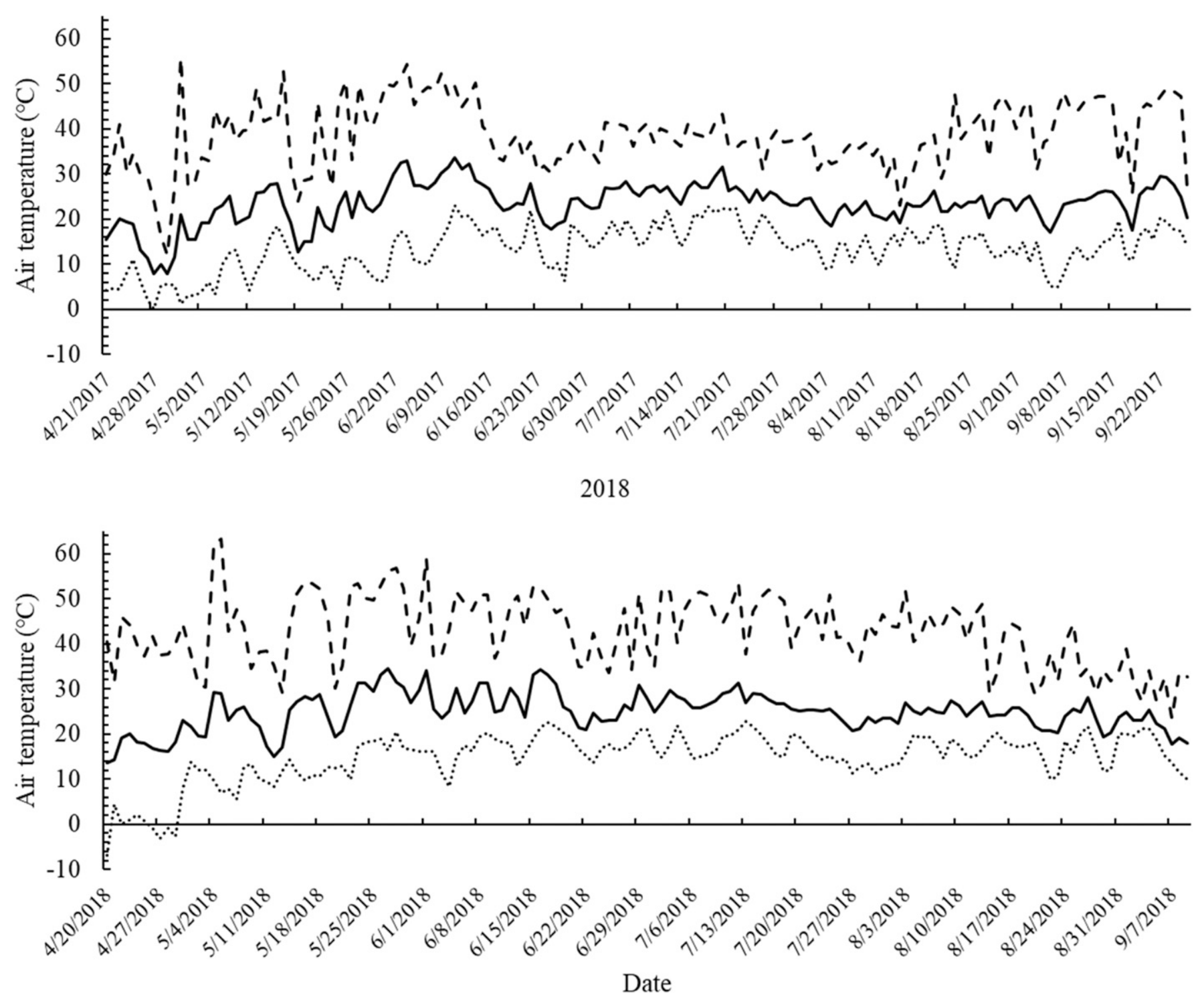

Min. - Avg. - - Max.

Fig. 1. Daily minimum, average, and maximum air temperature within the high tunnel during the 2017 and 2018 seasons at the Iowa State University Horticulture Research Station, Ames, IA. Data were collected every $1 \mathrm{~h}$ at $30 \mathrm{~cm}$ above the soil. Data were collected during the entire growing season in 2017 , but collection ceased on 9 Sept. in 2018 because of a sensor malfunction.

number of marketable fruit per plant (Tables 2 and 3). The weight of Grade 2 fruit was highest from '980 TRS' and 'Maxifort' in 2017 and 'Beaufort', 'DRO141TX', and 'Maxifort' in 2018 as compared with nongrafted 'BHN 589' (Table 3). 'DRO141TX' increased the weight of Grade 3 marketable fruit per plant in 2017 only (Table 3 ).

The total weight of nonmarketable fruit was highest from 'BHN 589' grafted to 'Arnold' and 'Beaufort' in both years, with the additions of 'DRO141TX' in 2017, and 'Maxifort' in 2018 (Table 3). In 2017, the only treatment that was different from the nongrafted control was 'RST-04-106-T', which had a higher weight of fruit with BER (Table 3). The results of fruit weight mirror those of fruit number for incidence of catfacing in 2018, but in 2017 fruit from the 'Beaufort' and 'DRO141TX' treatments had more catfacing compared with nongrafted plants as determined by weight (Table 3).

\section{Individual fruit weight}

The average weight of individual marketable fruit was higher than the nongrafted control in each year due to several rootstock combinations (Table 4). In 2017, fruit grown on 'Estamino' and '980 TRS' averaged the largest individual weights at 21.9 and $26.3 \mathrm{~g}$, respectively (Table 4). In 2018, 'BHN 589' grafted to 'Arnold', 'Beaufort', 'DRO141TX', 'Estamino', and 'Maxifort' led to average individual fruit weights between 32.7 ('DRO141TX') and $54.9 \mathrm{~g}$ ('Arnold') (Table 4).

\section{Fruit quality}

Firmness, SSC, $p H$, TTA, and SSC:TTA. There were no differences in firmness of fruit in either year (Table 5). SSC of fruit was unaffected in 2018; however, in 2017 fruit grown on 'Arnold' and 'Maxifort' had lower SSC as compared with nongrafted 'BHN 589' (Table 5). Fruit pH, TTA, and SSC:TTA were also not different among treatments in 2018 (Table 5). In 2017, both pH and TTA varied slightly among rootstock treatments but none were higher or lower than the nongrafted treatment, except for a lower $\mathrm{pH}$ 
Table 2. Effect of rootstock by year on mean number of marketable fruit per plant of Grades 1,2,3, and total fruit as well as the number of nonmarketable fruit per plant due to blossom end rot (BER) and catfacing, and total nonmarketable fruit of grafted, nongrafted, and self-grafted 'BHN 589' hybrid tomatoes grown in a high tunnel, Ames, IA, 2017 and 2018. ${ }^{\mathrm{z}}$

\begin{tabular}{|c|c|c|c|c|c|c|c|}
\hline \multirow[b]{2}{*}{ Rootstock } & \multicolumn{4}{|c|}{ No. of marketable fruit per plant ${ }^{y}$} & \multicolumn{3}{|c|}{ No. of nonmarketable fruit per plant ${ }^{\mathrm{x}}$} \\
\hline & Grade 1 & Grade 2 & Grade 3 & Total & BER & Catfacing & Total \\
\hline Nongrafted & $12.3 \mathrm{~b}^{\mathrm{w}}$ & $10.3 \mathrm{bc}$ & $6.1 \mathrm{~cd}$ & $28.7 \mathrm{c}$ & $0.76 \mathrm{bcd}$ & $2.04 \mathrm{ab}$ & $20.5 \mathrm{~b}$ \\
\hline 980 TRS & $13.8 \mathrm{~b}$ & $11.4 \mathrm{abc}$ & $6.9 \mathrm{bcd}$ & $32.1 \mathrm{bc}$ & $1.12 \mathrm{bc}$ & $1.92 \mathrm{ab}$ & $23.0 \mathrm{~b}$ \\
\hline Arnold & $18.1 \mathrm{a}$ & $11.2 \mathrm{abc}$ & $8.5 \mathrm{ab}$ & $37.9 \mathrm{ab}$ & $0.20 \mathrm{de}$ & $1.72 \mathrm{ab}$ & $33.1 \mathrm{a}$ \\
\hline Beaufort & $20.3 \mathrm{a}$ & $10.7 b c$ & $6.4 \mathrm{bcd}$ & $37.4 \mathrm{ab}$ & 0.48 cde & $2.60 \mathrm{a}$ & $26.6 \mathrm{ab}$ \\
\hline Maxifort & $19.0 \mathrm{a}$ & $13.7 \mathrm{a}$ & $8.4 \mathrm{abc}$ & $41.1 \mathrm{a}$ & $0.00 \mathrm{e}$ & $1.16 \mathrm{~b}$ & $32.8 \mathrm{a}$ \\
\hline RST-04-106-T & $12.7 \mathrm{~b}$ & $10.2 \mathrm{bc}$ & $6.2 \mathrm{~cd}$ & $29.1 \mathrm{c}_{2}$ & $2.20 \mathrm{a}$ & $1.36 \mathrm{~b}$ & $20.4 \mathrm{~b}$ \\
\hline Nongrafted & $6.2 \mathrm{~b}$ & $5.9 \mathrm{~b}$ & $3.3 \mathrm{ab}$ & $15.4 \mathrm{c}$ & $0.16 \mathrm{ab}$ & $0.20 \mathrm{c}$ & $8.9 \mathrm{~cd}$ \\
\hline Self-grafted & $5.2 \mathrm{~b}$ & $9.1 \mathrm{ab}$ & $3.4 \mathrm{ab}$ & $17.8 \mathrm{bc}$ & $0.03 \mathrm{ab}$ & $1.11 \mathrm{abc}$ & $10.9 \mathrm{abcd}$ \\
\hline 946 TRS & $8.3 \mathrm{~b}$ & $7.3 \mathrm{ab}$ & $3.6 \mathrm{ab}$ & $19.2 \mathrm{bc}$ & $0.00 \mathrm{~b}$ & $0.28 b c$ & $9.2 \mathrm{bcd}$ \\
\hline 980 TRS & $7.9 \mathrm{~b}$ & $6.7 \mathrm{ab}$ & $2.0 \mathrm{~b}$ & $16.6 \mathrm{c}$ & $0.00 \mathrm{~b}$ & $0.35 \mathrm{abc}$ & $6.6 \mathrm{~d}$ \\
\hline RST-04-106-T & $9.6 \mathrm{~b}$ & $8.0 \mathrm{ab}$ & $2.9 \mathrm{ab}$ & $20.5 \mathrm{bc}$ & $0.00 \mathrm{~b}$ & $0.44 \mathrm{abc}$ & $10.8 \mathrm{bcd}$ \\
\hline
\end{tabular}

${ }^{\mathrm{z}}$ Harvest took place 13 times each season from 5 July to 26 Sept. 2017 and 3 July to 25 Sept. 2018.

${ }^{\mathrm{y}}$ Grade 1: diameter $>5.9 \mathrm{~cm}$; Grade 2: $6.4 \mathrm{~cm}<$ diameter $<5.9 \mathrm{~cm}$, and Grade 3: $5.7 \mathrm{~cm}<$ diameter $<6.4 \mathrm{~cm}$.

${ }^{\mathrm{x}}$ Nonmarketable fruit was categorized as fruit smaller than $5.7 \mathrm{~cm}$ diameter, BER, catfacing, yellow shoulder, insects, or other surface defects.

${ }^{\mathrm{w}}$ Means followed by the same letter within the same column and year are not different according to the unrestricted least significant difference procedure ( $\left.\alpha=0.05\right)$.

Table 3. Effect of rootstock by year on mean weight of marketable fruit per plant of Grade 1, 2, 3, and total marketable fruit as well as weight of nonmarketable fruit per plant due to blossom end rot (BER) and catfacing, and total nonmarketable fruit of grafted, nongrafted, and self-grafted 'BHN 589' hybrid tomatoes grown in a high tunnel, Ames, IA, 2017 and $2018 .^{z}$

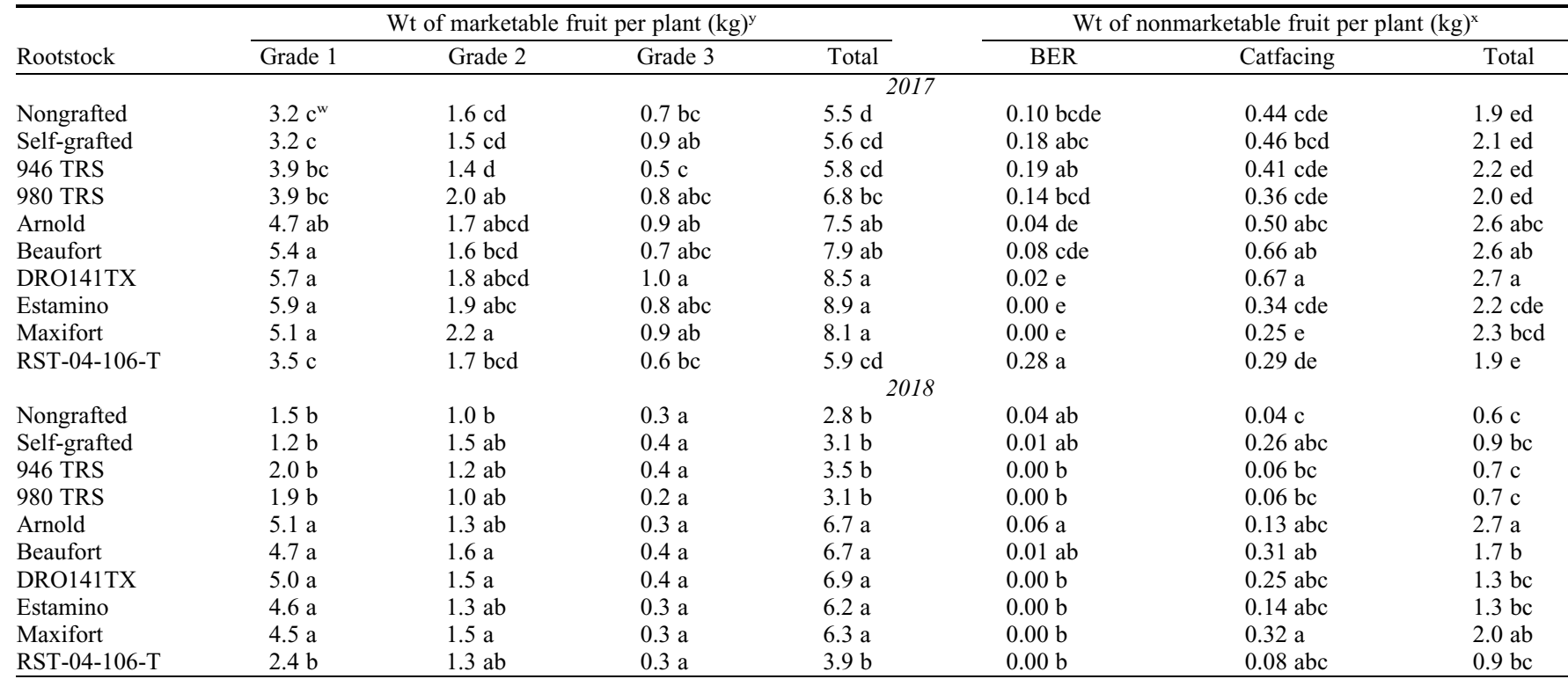

${ }^{\mathrm{z}}$ Harvest took place 13 times each season from 5 July to 26 Sept. 2017 and 3 July to 25 Sept. 2018.

${ }^{\mathrm{y}}$ Grade 1: diameter $>5.9 \mathrm{~cm}$; Grade $2: 6.4 \mathrm{~cm}<$ diameter $<5.9 \mathrm{~cm}$, and Grade $3: 5.7 \mathrm{~cm}<$ diameter $<6.4 \mathrm{~cm}$.

${ }^{\mathrm{x}}$ Nonmarketable: fruit smaller than $5.7 \mathrm{~cm}$ diameter, BER, catfacing, yellow shoulder, insects, or other surface defects.

${ }^{\mathrm{w}}$ Means followed by the same letter within the same column and year are not different according to the unrestricted least significant difference procedure $(\alpha=0.05)$.

in '946 TRS' (Table 5). The SSC:TTA ratio was the same among all treatments except for fruit grown on 'RST-04-106-T', which had a ratio of 20.84 in 2017 (Table 5).

\section{Plant growth}

In 2017, 'Arnold', 'Beaufort', 'DRO141TX', 'Estamino', and 'Maxifort' were all taller than nongrafted plants $(165 \mathrm{~cm})$, with heights ranging from 193 to $214 \mathrm{~cm}$ (Table 6). The end-of-season plant height in 2018 ranged from 184 to $210 \mathrm{~cm}$ for 'Arnold', 'Beaufort', 'DRO141TX', 'Estamino', and 'Maxifort', which was taller than the average height of $140 \mathrm{~cm}$ for nongrafted plants (Table 6).
The end-of-season stem diameter was largest on the same five rootstocks in each year (Table 6). Stem diameters of 'Arnold', 'Beaufort', 'DRO141TX', 'Estamino', and 'Maxifort' were 1.9 to $3.8 \mathrm{~mm}$ and 2.2 to $3.2 \mathrm{~mm}$ larger than those of nongrafted plants in 2017 and 2018, respectively (Table 6). 
Table 4. Effect of rootstock by year on mean weight of individual marketable fruit from of grafted, nongrafted, and self-grafted 'BHN 589' hybrid tomatoes grown in a high tunnel, Ames, IA, 2017 and $2018 .^{\mathrm{z}}$

\begin{tabular}{lcc}
\hline & \multicolumn{2}{c}{${\text { Individual marketable fruit } \mathrm{wt}(\mathrm{g})^{\mathrm{y}}}$} \\
\cline { 2 - 3 } Rootstock & \multicolumn{1}{c}{2017} & 2018 \\
\hline Nongrafted & $192.2 \mathrm{bc}^{\mathrm{x}}$ & $175.4 \mathrm{~d}$ \\
Self-grafted & $187.1 \mathrm{c}$ & $180.8 \mathrm{~cd}$ \\
946 TRS & $209.4 \mathrm{ab}$ & $181.6 \mathrm{~cd}$ \\
980 TRS & $218.5 \mathrm{a}$ & $190.1 \mathrm{~cd}$ \\
Arnold & $200.1 \mathrm{abc}$ & $230.3 \mathrm{a}$ \\
Beaufort & $211.1 \mathrm{ab}$ & $209.0 \mathrm{bc}$ \\
DRO141TX & $201.8 \mathrm{abc}$ & $208.1 \mathrm{bc}$ \\
Estamino & $214.1 \mathrm{a}$ & $216.9 \mathrm{ab}$ \\
Maxifort & $197.0 \mathrm{abc}$ & $213.2 \mathrm{abc}$ \\
RST-04-106-T & $202.2 \mathrm{abc}$ & $190.9 \mathrm{~cd}$ \\
\hline
\end{tabular}

${ }^{\mathrm{z}}$ Harvest took place 13 times each season from 5 July to 26 Sept. 2017 and 3 July to 25 Sept. 2018.

${ }^{\mathrm{y}}$ Individual marketable fruit weight $=$ Marketable fruit weight $/$ Marketable fruit no.

${ }^{\mathrm{x}}$ Means followed by the same letter within the same column and year are not different according to the unrestricted least significant difference procedure $(\alpha=0.05)$.

Table 5. Effect of rootstock by year on mean firmness, soluble solids content (SSC), $\mathrm{pH}$, total titratable acidity (TTA), and SSC:TTA of grafted, nongrafted, and self-grafted 'BHN 589' hybrid tomatoes grown in a high tunnel, Ames, IA, 2017 and 2018. ${ }^{\mathrm{z}}$

\begin{tabular}{llllll}
\hline Rootstock & Firmness (kgf) $^{\mathrm{y}}$ & SSC (\%) & $\mathrm{pH}$ & TTA (\% citric acid) & SSC:TTA (ratio) \\
\hline Nongrafted & $3.0 \mathrm{ab}^{\mathrm{x}}$ & $5.15 \mathrm{abc}$ & $4.4 \mathrm{ab}$ & $0.33 \mathrm{abc}$ & $16.24 \mathrm{~b}$ \\
Self-grafted & $3.1 \mathrm{ab}$ & $4.98 \mathrm{bcde}$ & $4.2 \mathrm{bc}$ & $0.38 \mathrm{ab}$ & $13.37 \mathrm{~b}$ \\
946 TRS & $3.1 \mathrm{ab}$ & $5.16 \mathrm{abc}$ & $4.2 \mathrm{c}$ & $0.40 \mathrm{a}$ & $13.12 \mathrm{~b}$ \\
980 TRS & $3.3 \mathrm{a}$ & $5.30 \mathrm{ab}$ & $4.2 \mathrm{bc}$ & $0.36 \mathrm{ab}$ & $14.62 \mathrm{~b}$ \\
Arnold & $3.0 \mathrm{ab}$ & $4.67 \mathrm{de}$ & $4.3 \mathrm{ab}$ & $0.32 \mathrm{bc}$ & $15.23 \mathrm{~b}$ \\
Beaufort & $3.2 \mathrm{ab}$ & $4.99 \mathrm{bcd}$ & $4.4 \mathrm{ab}$ & $0.33 \mathrm{abc}$ & $15.81 \mathrm{~b}$ \\
DRO141TX & $3.3 \mathrm{a}$ & $4.99 \mathrm{bcd}$ & $4.3 \mathrm{abc}$ & $0.35 \mathrm{ab}$ & $14.57 \mathrm{~b}$ \\
Estamino & $3.0 \mathrm{ab}$ & $4.94 \mathrm{cde}$ & $4.3 \mathrm{abc}$ & $0.36 \mathrm{ab}$ & $13.86 \mathrm{~b}$ \\
Maxifort & $2.8 \mathrm{~b}$ & $4.65 \mathrm{e}$ & $4.3 \mathrm{abc}$ & $0.32 \mathrm{bc}$ & $14.80 \mathrm{~b}$ \\
RST-04-106-T & $3.4 \mathrm{a}$ & $5.41 \mathrm{a}$ & $4.4 \mathrm{a}$ & $0.26 \mathrm{c}$ & $20.84 \mathrm{a}$ \\
& & & & & \\
Nongrafted & $2.7 \mathrm{a}$ & $5.03 \mathrm{a}$ & $4.5 \mathrm{a}$ & $0.32 \mathrm{a}$ & $16.91 \mathrm{a}$ \\
Self-grafted & $3.2 \mathrm{a}$ & $5.00 \mathrm{a}$ & $4.3 \mathrm{a}$ & $0.32 \mathrm{a}$ & $15.93 \mathrm{a}$ \\
946 TRS & $3.1 \mathrm{a}$ & $5.10 \mathrm{a}$ & $4.3 \mathrm{a}$ & $0.40 \mathrm{a}$ & $12.68 \mathrm{a}$ \\
980 TRS & $3.2 \mathrm{a}$ & $5.12 \mathrm{a}$ & $4.3 \mathrm{a}$ & $0.39 \mathrm{a}$ & $13.25 \mathrm{a}$ \\
Arnold & $2.5 \mathrm{a}$ & $5.08 \mathrm{a}$ & $4.5 \mathrm{a}$ & $0.31 \mathrm{a}$ & $16.66 \mathrm{a}$ \\
Beaufort & $2.8 \mathrm{a}$ & $5.18 \mathrm{a}$ & $4.4 \mathrm{a}$ & $0.35 \mathrm{a}$ & $14.96 \mathrm{a}$ \\
DRO141TX & $2.6 \mathrm{a}$ & $4.99 \mathrm{a}$ & $4.4 \mathrm{a}$ & $0.33 \mathrm{a}$ & $15.58 \mathrm{a}$ \\
Estamino & $2.8 \mathrm{a}$ & $5.07 \mathrm{a}$ & $4.4 \mathrm{a}$ & $0.36 \mathrm{a}$ & $14.73 \mathrm{a}$ \\
Maxifort & $2.7 \mathrm{a}$ & $4.83 \mathrm{a}$ & $4.4 \mathrm{a}$ & $0.36 \mathrm{a}$ & $13.78 \mathrm{a}$ \\
RST-04-106-T & $2.9 \mathrm{a}$ & $5.09 \mathrm{a}$ & $4.3 \mathrm{a}$ & $0.36 \mathrm{a}$ & $14.50 \mathrm{a}$ \\
\hline
\end{tabular}

${ }^{\mathrm{z}}$ Fully ripe fruit were harvested $125 \mathrm{~d}$ after transplanting (DAT) in 2017 and 116 DAT in 2018. One marketable fruit per plot was selected for analysis $(n=50)$.

${ }^{\mathrm{y}} \mathrm{kgf}=\mathrm{kilogram}$-force

${ }^{\mathrm{x}}$ Means followed by the same letter within the same column and year are not different according to the unrestricted least significant difference procedure $(\alpha=0.05)$.

Both end-of-season shoot and root biomass were affected by the use of tomato rootstocks (Fig. 2). In 2017, shoot biomass of 'Arnold', 'Beaufort', 'DRO141TX', 'Estamino', and 'Maxifort' was 59 to $100 \mathrm{~g}$ more than nongrafted plants. In 2018 , there were more differences among treatments, with 'Maxifort' and 'DRO141TX' having the largest shoot biomasses at 386 and $315 \mathrm{~g}$, respectively; however, the shoot biomass of 'DRO141TX' was also similar to those of 'Arnold', 'Beaufort', and 'Estamino' (Fig. 2).

Overall, the root biomass was much larger for all treatments in 2017 as compared with 2018 (Fig. 2). 'Arnold', 'Beaufort', 'Estamino', and 'RST-04-106-T' had larger root biomasses than nongrafted and self-grafted plants, as well as '946 TRS' and '980 TRS' in 2017. In 2018, 'RST-04-106-T' had a biomass similar to nongrafted and self-grafted plants, '946 TRS', and '980 TRS', with the other five rootstocks having larger root systems (Fig. 2).

\section{Discussion}

Our research assumed that soilborne disease pressure was absent or minimal, which was found to be true based on observations within the high tunnel during both seasons. Under Midwest soil conditions, the rootstocks 'Arnold', 'DRO141TX', and 'Estamino' performed as well as 'Beaufort' and 'Maxifort' when grafted to the scion 'BHN 589'. Our study is the first published report on the performance of 'DRO141TX' tomato rootstock and the only study of yield response of 'Estamino' rootstock.

The number and weight of marketable and total fruit per plant found in our experiment was comparable to other trials of nongrafted and grafted 'BHN 589' conducted in Midwest high tunnels (Loewen, 2018; Meyer, 2016). Yields were slightly lower in 2018 as compared with 2017 , which may have been the result of the high heat damage early in the growing season. The number of culled fruit due to either BER or catfacing was relatively low in both years; however, both insect damage and fruit cracking were prevalent, especially in 2017. Improvements in irrigation and pest management were likely responsible for the reduction in total nonmarketable fruit in 2018.

'Maxifort' is now considered a "standard" tomato rootstock (Grieneisen et al., 2018) with its ability to increase yield confirmed in multiple studies (Kunwar et al., 2015; Loewen, 2018; Masterson et al., 2016; Meyer, 2016). The yield increases we observed on the 'Maxifort' rootstock align with previous findings. 'Beaufort' is another rootstock that is being widely tested, although not all yield responses have been positive (Buller et al., 2013). Most recently, this rootstock has been shown to improve yields (Djidonou et al., 2013, 2017; Turhan et al., 2011) and improve water use efficiency (Suchoff et al., 2018b). Our results add evidence that 'Beaufort' is a useful rootstock for increasing yield. The rootstock 'Arnold' has been shown to increase yield under ambient field conditions (Di Gioia et al., 2013; Meyer, 2016; Turhan et al., 2011) as well as respond favorably to mild levels of elevated soil salinity (Di Gioia et al., 2013). Our findings of 'Arnold' performing well within disease-free soil conditions align with the work of preceding studies. The only research on the rootstock 'Estamino' demonstrated that it may not be a suitable rootstock for decreasing the incidence of verticillium wilt (Miles et al., 2015); however, based on our research, the rootstock should be included in future studies aimed at improving crop yields in sites where this disease is not problematic. 'RST-04-106T' performed poorly in our study, which was not surprising based on previous work in Iowa (Lang and Nair, 2019); however, recent work conducted in North Carolina confirms that this rootstock still remains a valuable tool in resisting bacterial wilt and mitigating yield reductions due to the disease (Suchoff et al., 2019).

The weight of individual marketable fruit in our study was somewhat higher than other reports using the same rootstocks (Djidonou et al., 2013, 2017; Meyer, 2016), although it is difficult to make direct comparisons due to differences in scions evaluated; however, the general trend we observed in our data aligns with the findings of the previously cited studies. The effect of grafting on individual fruit weight is not as large as the effect on overall yield increase and may be attributed to a disproportionate increase in the number of fruit as compared with overall fruit weight per plant.

Differences in fruit quality parameters were minimal and observed only in one year (2017) of our research. The values we found 
for SSC, $\mathrm{pH}$, and TTA were similar to results of prior research (Di Gioia et al., 2013; Djidonou et al., 2017; Nicoletto et al., 2013). The effect of grafting on tomato fruit quality appears to be minimal, as recently confirmed by a meta-analysis of tomato grafting research that found nonsignificant effects of grafting in more than $75 \%$ of
Table 6. Effect of rootstock by year on mean end-of-season stem diameter and plant height of grafted, nongrafted, and self-grafted 'BHN 589' hybrid tomatoes grown in a high tunnel, Ames, IA, 2017 and $2018 .^{\mathrm{z}}$

\begin{tabular}{lllll}
\hline & \multicolumn{2}{c}{ Stem diam $(\mathrm{mm})$} & \multicolumn{2}{c}{ Plant ht $(\mathrm{cm})$} \\
\cline { 2 - 3 } Rootstock & 2017 & 2018 & 2017 & $140.1 \mathrm{c}$ \\
\hline Nongrafted & $15.7 \mathrm{~d}^{\mathrm{y}}$ & $14.1 \mathrm{~b}$ & $165.1 \mathrm{c}$ & $145.6 \mathrm{bc}$ \\
Self-grafted & $16.1 \mathrm{~cd}$ & $16.0 \mathrm{ab}$ & $178.0 \mathrm{bc}$ & $152.2 \mathrm{bc}$ \\
946 TRS & $17.0 \mathrm{bcd}$ & $14.6 \mathrm{~b}$ & $157.5 \mathrm{c}$ & $132.6 \mathrm{c}$ \\
980 TRS & $15.6 \mathrm{~d}$ & $14.2 \mathrm{~b}$ & $153.8 \mathrm{c}$ & $191.4 \mathrm{ab}$ \\
Arnold & $18.0 \mathrm{ab}$ & $16.8 \mathrm{a}$ & $206.2 \mathrm{ab}$ & $184.0 \mathrm{ab}$ \\
Beaufort & $17.6 \mathrm{abc}$ & $16.4 \mathrm{a}$ & $198.8 \mathrm{ab}$ & $206.7 \mathrm{a}$ \\
DRO141TX & $19.5 \mathrm{a}$ & $17.3 \mathrm{a}$ & $193.7 \mathrm{ab}$ & $192.8 \mathrm{ab}$ \\
Estamino & $18.2 \mathrm{ab}$ & $16.3 \mathrm{a}$ & $214.8 \mathrm{a}$ & $210.0 \mathrm{a}$ \\
Maxifort & $18.1 \mathrm{ab}$ & $18.2 \mathrm{a}$ & $202.6 \mathrm{ab}$ & $147.9 \mathrm{bc}$ \\
RST-04-106-T & $16.6 \mathrm{bcd}$ & $14.5 \mathrm{~b}$ & $179.5 \mathrm{bc}$ & $\mathrm{c}$
\end{tabular}

${ }^{\mathrm{z}}$ The same three plants were used for stem diameter and plant height measurements at 152 and $158 \mathrm{~d}$ after transplanting in 2017 and 2018, respectively. Stem diameter was measured using digital calipers $1 \mathrm{~cm}$ above the graft union for all grafted treatments and $2 \mathrm{~cm}$ above the soil line for nongrafted controls. Plant height was measured from the soil line to the growing point of each plant.

${ }^{\mathrm{y}}$ Means followed by the same letter within the same column and year are not different according to the unrestricted least significant difference procedure $(\alpha=0.05)$. studies that evaluated $\mathrm{pH}, \mathrm{TTA}, \mathrm{SSC}$, and firmness (Grieneisen et al., 2018). Although the work of Grieneisen et al. (2018) demonstrates that grafting will not reduce fruit quality in most cases, measurement of these parameters should still be included in future scion $\times$ rootstock evaluations, as select cases have shown stark differences in fruit quality effects.

Plant height as affected by grafting has not often been reported in other studies, which instead favor reporting overall plant biomass (Barrett et al., 2012b; Loewen, 2018; Meyer, 2016). However, we argue that reporting overall plant height is important, especially as it relates to management decisions. The unexpected level of growth that we observed created management challenges with the stake and weave trellis system inside of the high tunnel. Excessive plant height may be a concern for high tunnel growers trying to optimize production in a limited amount of space. Future work that identifies scion-rootstock combinations that stay shorter and minimize staking and pruning without
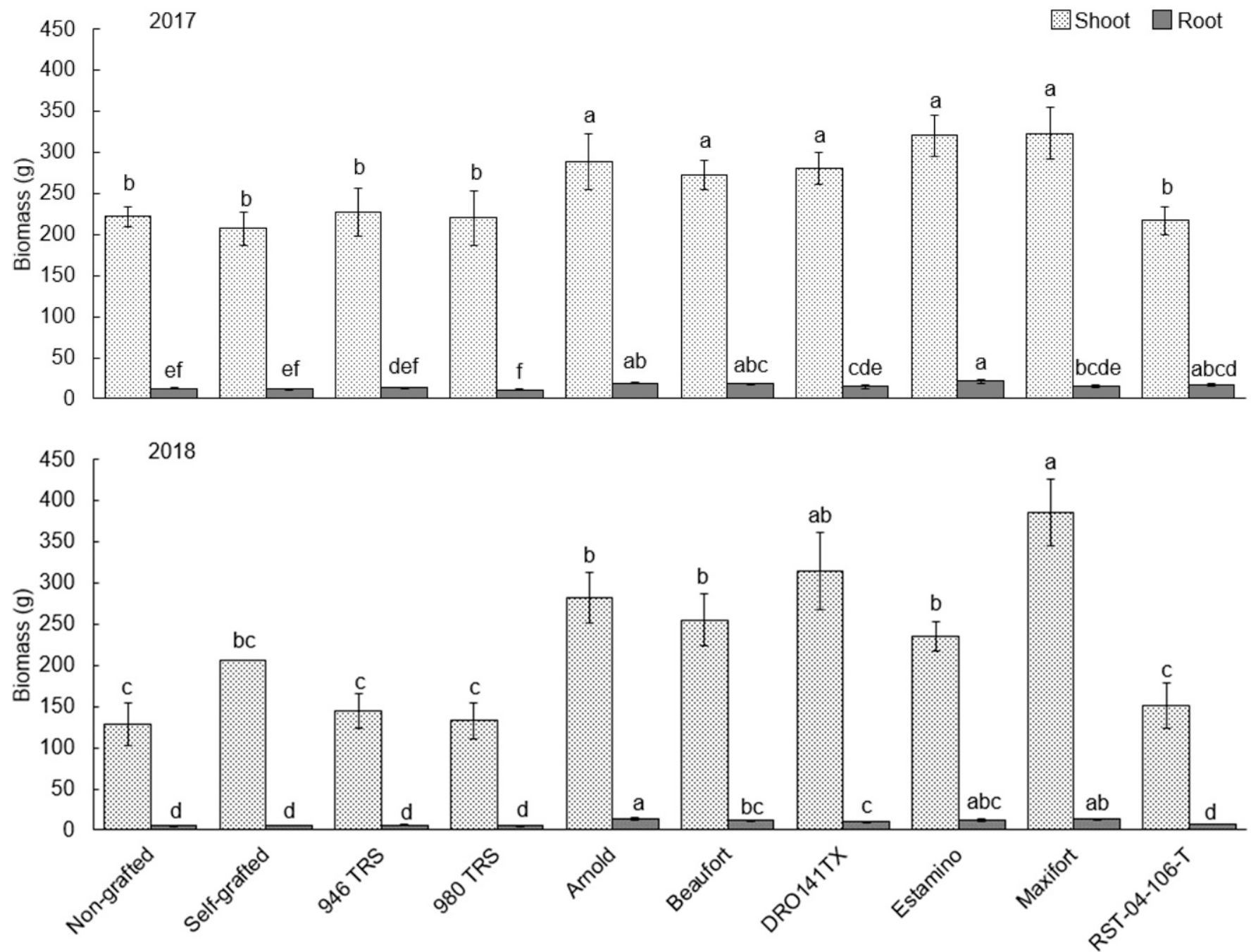

Rootstock

Fig. 2. Effect of rootstock by year on mean shoot and root biomass (g) of grafted, nongrafted, and self-grafted 'BHN 589' hybrid tomatoes grown at the Iowa State University Horticulture Research Station, Ames, IA, in 2017 and 2018. Means with common letters within a response variable (shoot or root) are not different according to the unrestricted least significant difference procedure $(\alpha=0.05)$. Bars represent the error of the mean. 
yield decreases will be beneficial for high tunnel growers.

The stem diameters measured in this study were greater than those observed in our previous research (Lang and Nair, 2019). The increased stem diameter as a response to grafting aligns with previous, albeit limited, reports (Buller et al., 2013; Lang and Nair, 2019).

Grafting has generally been shown to increase scion shoot biomass, and in turn promote yield increases (Kunwar et al., 2015; Loewen, 2018; Meyer, 2016). Our results align with these findings, as the rootstocks 'Arnold', 'Beaufort', 'DRO141TX', 'Estamino', and 'Maxifort' each had the highest yield as well as the largest shoot biomass in both seasons. In 2018, 'Arnold', 'Beaufort', and 'Estamino' had less shoot biomass compared with 'Maxifort' without reductions in yield. Although only observed in 1 year, this result may indicate that these rootstocks have greater yield to biomass efficiency.

Morphology of the root systems of hybrid tomato rootstocks has not been well understood; however, work in this area is ongoing (Suchoff et al., 2017, 2018b). Within both seasons, we found increased root biomass for 'Arnold', 'Beaufort', and 'Estamino' rootstocks. Differences in root width and root length may affect overall root biomass and have important implications for both water and nutrient uptake; however, soil texture and structure will both affect rootstock performance at a given location (Suchoff et al., $2017,2018 b$ ). It seems imperative that more trials of tomato rootstocks report root biomass to aid in understanding the interaction between rootstocks of varying morphologies in multiple soil types.

\section{Conclusions}

Our work demonstrated that 'BHN 589' grafted to 'Arnold', 'DRO141TX', or 'Estamino' can yield as well as 'BHN 589' grafted to 'Beaufort' or 'Maxifort' in typical Midwest high tunnel conditions. We demonstrated that fruit quality was not affected by the rootstocks used, but plant growth was generally greater for five of the rootstocks in our study. Our findings are relevant for Midwest high tunnel production of tomatoes under low disease pressure in the absence of other abiotic stresses, and these results expand the selection of rootstocks that Midwest growers can choose from when incorporating grafting into their production systems. Future exploration of the applications of 'Arnold', 'DRO141TX', and 'Estamino' rootstocks could be of great value to tomato growers across the United States.

\section{Literature Cited}

Albacete, A., C. Martínez-Andújar, A. MartínezPérez, A.J. Thompson, I.C. Dodd, and F. PérezAlfocea. 2015. Unravelling rootstock $\times$ scion interactions to improve food security. J. Expt. Bot. 66:2211-2226.

Barrett, C.E., X. Zhao, and A.W. Hodges. 2012a. Cost benefit analysis of using grafted transplants for root-knot nematode management in organic heirloom tomato production. HortTechnology 22:252-257.

Barrett, C.E., X. Zhao, and R. McSorley. 2012b. Grafting for root-knot nematode control and yield improvement in organic heirloom tomato production. HortScience 47:614-620.

Bhatt, R.M., K.K. Upreti, M.H. Divya, S. Bhat, C.B. Pavithra, and A.T. Sadashiva. 2015. Interspecific grafting to enhance physiological resilience to flooding stress in tomato (Solanum lycopersicum L.). Scientia Hort. 182:8-17.

Bruce, A.B., J.R. Farmer, E.T. Maynard, and J.C.D. Valliant. 2017. Assessing the impact of the EQIP High Tunnel Initiative. J. Agr. Food Systems Community Dev. 7:159-180.

Bruce, A.B., E.T. Maynard, and J.R. Farmer. 2019 Farmers' perspectives on challenges and opportunities associated with using high tunnels for specialty crops. HortTechnology 29:290299.

Buller, S., D. Inglis, and C. Miles. 2013. Plant growth, fruit yield and quality, and tolerance to verticillium wilt of grafted watermelon and tomato in field production in the Pacific Northwest. HortScience 48:1003-1009.

Carey, E.E., L. Jett, W.J. Lamont, T.T. Nennich, M.D. Orzolek, and K.A. Williams. 2009. Horticultural crop production in high tunnels in the United States: A snapshot. HortTechnology 19:37-43.

Di Gioia, F., A. Signore, F. Serio, and P. Santamaria. 2013. Grafting improves tomato salinity tolerance through sodium partitioning within the shoot. HortScience 48:855-862.

Djidonou, D., A.H. Simonne, K.E. Koch, J.K. Brecht, and X. Zhao. 2016. Nutritional quality of field-grown tomato fruit as affected by grafting with interspecific hybrid rootstocks. HortScience 51:1618-1624.

Djidonou, D., K. Lopiano, X. Zhao, E.H. Simonne, J.E. Erickson, and K.E. Koch. 2015. Estimating nitrogen nutritional crop requirements of grafted tomatoes under field conditions. Scientia Hort. 182:18-26.

Djidonou, D., X. Zhao, E.H. Simonne, K.E. Koch, and J.E. Erickson. 2013. Yield, water-, and nitrogen-use efficiency in field-grown, grafted tomatoes. HortScience 48:485-492.

Djidonou, D., X. Zhao, J.K. Brecht, and K.M. Cordasco. 2017. Influence of interspecific hybrid rootstocks on tomato growth, nutrient accumulation, yield, and fruit composition under greenhouse conditions. HortTechnology 27:868-877.

Enderton, A., C. Bregendahl, D. Swenson, and L. Adcock. 2017. Iowa commercial horticulture food crop survey results. Iowa Dept. of Ag. and Land Stewardship, Des Moines, IA Iowa State Univ. Extension and Outreach, Ames, IA. <https://www.iowaagriculture.gov/ Horticulture_and_FarmersMarkets/pdfs/2017/ Hort\%20Survey_SINGLEPAGE_BLEED_ 0322.pdf>.

Galinato, S.P. and C.A. Miles. 2013. Economic profitability of growing lettuce and tomato in western Washington under high tunnel and open-field production systems. HortTechnology 23:453-461.

Gent, M.P.N. 1992. Effect of planting date, ventilation and soil temperature on growth and nutrition of tomato in high tunnels. Plant Soil 145:81-91.

Grieneisen, M.L., B.J. Aegerter, S.C. Stoddard, and M. Zhang. 2018. Yield and fruit quality of grafted tomatoes, and their potential for soil fumigant use reduction. A meta-analysis. Agron. Sustain. Dev. 38:29.
Knewtson, S.J.B., R. Janke, M.B. Kirkham, K.A. Williams, and E.E. Carey. 2010. Trends in soil quality under high tunnels. HortScience 45: 1534-1538.

Kubota, C., M.A. McClure, N. Kokalis-Burelle, M.G. Bausher, and E.N. Rosskopf. 2008. Vegetable grafting: History, use, and current technology status in North America. HortScience 43:1664-1669.

Kunwar, S., M.L. Paret, S.M. Olson, L. Ritchie, J.R. Rich, J. Freeman, and T. McAvoy. 2015. Grafting using rootstocks with resistance to Ralstonia solanacearum against Meloidogyne incognita in tomato production. Plant Dis. 99:119-124.

Lamont, W.J. 2009. Overview of the use of high tunnels worldwide. HortTechnology 19:25-29.

Lang, K.M. and A. Nair. 2019. Effect of tomato rootstock on hybrid and heirloom tomato performance in a Midwest high tunnel production system. HortScience 54:840-845.

Lee, J.M., C. Kubota, S.J. Tsao, Z. Bie, P.H. Echevarria, L. Morra, and M. Oda. 2010. Current status of vegetable grafting: Diffusion, grafting techniques, automation. Scientia Hort. 127:93-105.

Leonardi, C. and F. Giuffrida. 2006. Variation of plant growth and macronutrient uptake in grafted tomatoes and eggplants on three different rootstocks. Eur. J. Hort. Sci. 71:97-101. $<$ http://www.jstor.org/stable/24126634>.

Liu, N., B. Zhou, X. Zhao, B. Lu, Y. Li, and J. Hao. 2009. Grafting eggplant onto tomato rootstock to suppress Verticillium dahliae infection: The effect of root exudates. HortScience 44:20582062.

Loewen, D. 2018. Tomato and pepper grafting for high tunnel production: Effects on yield, compatibility, and plant morphology. Kansas State Univ., Manhattan, MS Thesis. <http://hdl. handle.net/2097/39078>.

Louws, F.J., C.L. Rivard, and C. Kubota. 2010. Grafting fruiting vegetables to manage soilborne pathogens, foliar pathogens, arthropods and weeds. Scientia Hort. 127:127-146.

Martinez-Rodriguez, M.M., M.T. Estañ, E. Moyano, J.O. Garcia-Abellan, F.B. Flores, J.F. Campos, M.J. Al-Azzawi, T.J. Flowers, and M.C. Bolarín. 2008. The effectiveness of grafting to improve salt tolerance in tomato when an 'excluder' genotype is used as scion. Environ. Exp. Bot. 63:392-401.

Masterson, S.A., M.M. Kennelly, R.R. Janke, and C.L. Rivard. 2016. Scion shoot removal and rootstock cultivar affect vigor and early yield of grafted tomatoes grown in high tunnels in the central United States. HortTechnology 26:399-408.

McAvoy, T., J.H. Freeman, S.L. Rideout, S.M. Olson, and M.L. Paret. 2012. Evaluation of grafting using hybrid rootstocks for management of bacterial wilt in field tomato production. HortScience 47:621-625.

Meyer, L. 2016. Grafting to increase high tunnel tomato productivity in the central United States. Kansas State Univ., Manhattan, MS Thesis. <http://hdl.handle.net/2097/32736>.

Miles, C., J. Wimer, and D. Inglis. 2015. Grafting eggplant and tomato for verticillium wilt resistance. Acta Hort 1086:113-118.

Nicoletto, C., F. Tosini, and P. Sambo. 2013. Effect of grafting on biochemical and nutritional traits of "Cuore di Bue" tomatoes harvested at different ripening stages. Acta Agr. Scand. Sect. B 63:114-122.

Nilsen, E.T., J. Freeman, R. Grene, and J. Tokuhisa. 2014. A rootstock provides water conservation for a grafted commercial tomato (Solanum lycopersicum L.) line in response to mild- 
drought conditions: A focus on vegetative growth and photosynthetic parameters. PLoS One 9:1-22.

Ntatsi, G., D. Savvas, G. Ntatsi, H.-P. Kläring, and D. Schwarz. 2014. Growth, yield, and metabolic responses of temperature-stressed tomato to grafting onto rootstocks differing in cold tolerance. J. Amer. Soc. Hort. Sci. 139:230 243.

O’Connell, S., C. Rivard, M.M. Peet, C. Harlow, and F. Louws. 2012. High tunnel and field production of organic heirloom tomatoes: Yield, fruit quality, disease, and microclimate. HortScience 47:1283-1290.

Reeve, J. and D. Drost. 2012. Yields and soil quality under transitional organic high tunnel tomatoes. HortScience 47:38-44.

Rivard, C.L. and F.J. Louws. 2008. Grafting to manage soilborne diseases in heirloom tomato production. HortScience 43:2104-2111.

Rivard, C.L., S. O'Connell, M.M. Peet, and F.J. Louws. 2010a. Grafting tomato with interspecific rootstock to manage diseases caused by Sclerotium rolfsii and southern root-knot nematode. Plant Dis. 94:1015-1021.

Rivard, C.L., O. Sydorovych, S. O'Connell, M.M. Peet, and F.J. Louws. 2010b. An economic analysis of two grafted tomato transplant production systems in the United States. HortTechnology 20:794-803.

Schwarz, D., G.B. Öztekin, Y. Tüzel, B. Brückner, and A. Krumbein. 2013. Rootstocks can enhance tomato growth and quality characteristics at low potassium supply. Scientia Hort. 149:70-79.

Schwarz, D., Y. Rouphael, G. Colla, and J.H. Venema. 2010. Grafting as a tool to improve tolerance of vegetables to abiotic stresses: Thermal stress, water stress and organic pollutants. Scientia Hort. 127:162-171.

Suchoff, D.H., C.C. Gunter, and F.J. Louws. 2017. Comparative analysis of root system morphology in tomato rootstocks. HortTechnology 27:319-324.

Suchoff, D.H., P. Perkins-Veazie, H.W. Sederoff, J.R. Schultheis, M.D. Kleinhenz, F.J. Louws, and C.C. Gunter. 2018a. Grafting the indeterminate tomato cultivar Moneymaker onto Multifort rootstock improves cold tolerance. HortScience 53:1610-1617.

Suchoff, D.H., J.R. Schultheis, M.D. Kleinhenz, F.J. Louws, and C.C. Gunter. 2018b. Rootstock improves high-tunnel tomato water use efficiency. HortTechnology 28:344-353.

Suchoff, D.H., F.J. Louws, and C.C. Gunter. 2019. Yield and disease resistance for three bacterial wilt-resistant tomato rootstocks. HortTechnology 29:330-337.

Sydorovych, O., C.L. Rivard, S. O'Connell, C.D. Harlow, M.M. Peet, and F.J. Louws. 2013. Growing organic heirloom tomatoes in the field and high tunnels in North Carolina: Comparative economic analysis. HortTechnology 23:227-236.

Taber, H., P. Perkins-Veazie, S. Li, W. White, S. Rodermel, and Y. Xu. 2008. Enhancement of tomato fruit lycopene by potassium is cultivar dependent. HortScience 43:159-165.

Turhan, A., N. Ozmen, M.S. Serbeci, and V. Seniz. 2011. Effects of grafting on different rootstocks on tomato fruits yield and quality. Hort. Sci. (Prague) 38:142-149.

U.S. Department of Agriculture. 1991a. United States standards for grades of fresh tomatoes
(Size §51.1859). U.S. Dept. Agr., Washington, DC. 3 Jan. 2019. <https://www.ams.usda.gov/ sites/default/files/media/Tomato_Standard $\% 5 \mathrm{~B} 1 \%$ 5D.pdf>.

U.S. Department of Agriculture. 1991b. United States standards for grades of fresh tomatoes (color classification \$51.1860). U.S. Dept. Agr., Washington, DC. 3 Jan. 2019. <https:// www.ams.usda.gov/sites/default/files/media/ Tomato_Standard\%5B1\%5D.pdf $>$.

U.S. Department of Agriculture, National Agricultural Statistics Service. 2019a. 2017 Census of Agriculture. Volume 1: Chapter 1: Iowa State Level Data. Table 39. Floriculture and bedding crops, nursery crops, propagative materials sold, sod, food crops grown under glass or other protection, and mushroom crops: 2017 and 2012. U.S. Dept. Agr., Washington, DC.

U.S. Department of Agriculture, National Agricultural Statistics Service. 2019b. 2017 Census of Agriculture. Volume 1, Chapter 1: Iowa State Level Data. Table 36: Vegetables, potatoes, and melons harvested for sale: 2017 and 2012. U.S. Dept. Agr., Washington, DC.

Vitale, A., M. Rocco, S. Arena, F. Giuffrida, C. Cassaniti, A. Scaloni, T. Lomaglio, V. Guarnaccia, G. Polizzi, M. Marra, and C. Leonardi. 2014. Tomato susceptibility to Fusarium crown and root rot: Effect of grafting combination and proteomic analysis of tolerance expression in the rootstock. Plant Physiol. Biochem. 83:207-216.

Waterer, D. 2003. Yields and economics of high tunnels for production of warm-season vegetable crops. HortTechnology 13:339-343. 